\title{
Chapter 4 \\ Genetic Variation and Agronomic Features of Metroxylon Palms in Asia and Pacific
}

\author{
Hiroshi Ehara
}

\begin{abstract}
Fourteen genera among three subfamilies in the Arecaceae family are known to produce starch in the trunk. The genus Metroxylon is the most productive among them and is classified into section Metroxylon including only one species, $M$. sagu (sago palm: called the true sago palm), distributed in Southeast Asia and Melanesia and section Coelococcus consisting of $M$. amicarum in Micronesia, $M$. salomonense and $M$. vitiense in Melanesia, M. warburgii in Melanesia and Polynesia, and M. paulcoxii in Polynesia. In sago palm, a relationship between the genetic distance and geographical distribution of populations was found as the result of a random amplified polymorphic DNA analysis. A smaller genetic variation of sago palm in the western part than in the eastern part of the Malay Archipelago was also found, which indicated that the more genetically varied populations are distributed in the eastern area and are possibly divided into four broad groups. Metroxylon warburgii has a smaller trunk than sago palm, but the trunk length of $M$. salomonense, $M$. vitiense, and $M$. amicarum is comparable to or longer than that of sago palm. Their leaves are important as building and houseware material, and the hard endosperm of $M$. amicarum and $M$. warburgii seeds is utilized as craftwork material. Preemergent young leaves around the growing point of $M$. vitiense are utilized as a vegetable. Regarding starch yield, palms in Coelococcus are all low in the dry matter and pith starch content as compared with sago palm. For this reason, $M$. salomonense and $M$. amicarum have low yield despite the large size of their trunk. Palms in Coelococcus are mostly regarded as emergency crops and had been utilized when major crops suffered climate damage. Today, roof thatching is the most common use of the leaves, and the domestication of $M$. warburgii is currently under way in Vanuatu and Samoa.
\end{abstract}

The Arecaceae family includes six subfamilies, about 200 genera, and 2600 species. Among three subfamilies (Coryphoideae, Calamoidea, and Arecoideae), 14 genera (Corypha, Phoenix, Borassus, Eugeissona, Metroxylon, Raphia, Mauritia, Caryota,

\footnotetext{
H. Ehara ( $\square)$

Applied Social System Institute of Asia; International Cooperation Center for Agricultural

Education, Nagoya University, Nagoya, Japan

e-mail: ehara@agr.nagoya-u.ac.jp
} 
Wallichia, Roystonea, Butia, Syagrus, and Bactris) produce carbohydrates in the trunk. Considering starch yield, the genus Metroxylon is recognized as the most promising. The genus Metroxylon is distributed from Southeast Asia to Micronesia, Melanesia, and Polynesia. It is divided into two sections: Metroxylon (Eumetroxylon) and Coelococcus (Beccari 1918; Rauwerdink 1986). Metroxylon sagu Rottb. (called the true sago palm: hereafter sago palm) is the only species in the section Metroxylon, although the monophyly of this section remains uncertain. Sago palm extends across Southeast Asia (Thailand, Malaysia, Brunei, Indonesia, Philippines) and northwestern Melanesia (Papua New Guinea and the Solomon Islands). This species has long been used as a food similar to bananas and taro (Barrau 1959) and is one of the oldest crops used by human beings since ancient times (Takamura 1990). The sago-type palms were an important plant food prior to the introduction of rice (around 5000 years ago) in south subtropical China (Yang et al. 2013). Five species are recognized within the section Coelococcus, representing the eastern half of the Metroxylon distributing area (McClatchey 1998; Ehara 2015a). One species is distributed in Micronesia, and the other four species are distributed across Melanesia and Polynesia from the Solomon Islands and Vanuatu to Fiji and Samoa. McClatchey (1998) reported that people on Rotuma in Fiji consume sago (starch obtained from the palm trunk) produced from M. warburgii. Metroxylon warburgii is sometimes called the Vanuatu sago palm. In other areas, Metroxylon palms have been used occasionally. For instance, $M$. amicarum (Caroline ivory nut palm) was used on Moen in Micronesia until the 1940s, and M. warburgii was used on Gaua in Vanuatu until at least the 1950s (Ehara et al. 2003c). On Malekula in Vanuatu, M. warburgii is sometimes used as an emergency food. Indo-Fijian people often harvest $M$. vitiense (Fijian sago palm) to get the preemergent young leaves around the growing point (apical bud together with the very young leaf sheathes and leaves) (Ehara 2015c). The harvested part recognized as palm cabbage is used for cooking similar to bamboo shoot. The leaves of Metroxylon palms are important as building and houseware materials. The hard endosperm of $M$. amicarum and $M$. warburgii seeds is called palm ivory and utilized as craftwork material (Ehara 2015d).

Sago palm and related species grow in swampy, alluvial, and peaty soils where almost no other major crops can grow without drainage or soil improvement (Sato et al. 1979; Jong 1995). Sago palm is a highly important bioresource for not only sustainable agriculture but also rural development in swampy areas of the tropics. Moreover, Metroxylon palms, including sago palm, are recognized as unexploited or underexploited plants (Ehara 2006a) because this species has been harvested mainly from natural forests and/or has been semi-cultivated with very simple maintenance.

Considering the recent social background that a new competition between biofuel production and food production has occurred, and as food demands diversify, an efficient use of carbohydrates from sago palm and related species is currently anticipated, followed by a predicted increase in the development and utilization of land in swampy areas. According to the Department of Agriculture, Sarawak, the amount of sago starch exported from Malaysia was about 44,500 mt in 2010 and 
51,000 $\mathrm{mt}$ in 2011. A private company in Riau, Indonesia, is planning to export around $1000 \mathrm{mt}$ of sago starch annually. Sago palm's presence is actually not high in the international starch market at present. However, considering the estimated sago palm-growing area (distribution) in Southeast Asia and Melanesia (see Chap. 1), sago palm's potential will be extremely high in carbohydrate supply for various industries. The establishment of a concrete system for stable and sustainable production is a pressing demand to enhance the further use of sago palm to strengthen food security for all. This chapter provides a brief review of the genetic variation and agronomic features of Metroxylon palms in Asia and the Pacific.

\subsection{Variation in the Plant Form, Palm Size, and Starch Yield}

Key characters to classification of the genus Metroxylon are shown in Table 4.1. Palms belonging to the Calamoideae subfamily of the Arecaceae, including the genus Metroxylon, produce fruits that are covered with scales. The sago palm produces fruits with 18 rows of longitudinally arranged scales. The other species in the section Coelococcus bear 24-28 rows of scales. Sago palm can be propagated from both seeds and suckers; however, the germination percentage of seeds is very low. The Coelococcus palms are apparently different from sago palm because they do not produce suckers. Instead, the germination percentage of seeds is very high in the section Coelococcus, and those palms depend for their propagation on only the seeds. Regarding distinct characteristics of the inflorescence, only M. amicarum grows lateral inflorescences from leaf axils, while the other five species produce a terminal racemose inflorescence (Fig. 4.1). The lateral inflorescence of M. amicarum is pleonanthic (polycarpic), but the terminal inflorescence of the other species is hapaxanthic (monocarpic). There are variations in the branching system, pattern, and fruit shape. According to Rauwerdink (1986), second-order branches on $M$. salomonense and $M$. warburgii are not pendulous. The second-order branches on the inflorescence of $M$. vitiense are pendulous. Dowe (1989) reported the variation in the second- and third-order branching system of the inflorescence of $M$. salomonense. The different second-order branching patterns are found even on a single first-order branch of M. salomonense (Ehara et al. 2003b). Metroxylon salomonense grows rachillae as third-order branches on a second-order branch; the second-order branch grows erect on the first-order branch. Then, the rachillae are formed on first-order branches as second-order branches in some cases, and these second-order branches (rachillae) are pendulous in such cases. Regarding distinct characteristics of spines on the petiole and rachis, $M$. vitiense forms black spines, and $M$. salomonense has soft and flexible fibrous spines unlike any other species.

Sago palm produces the largest amount of starch depending on its higher dry matter percentage in pith and starch concentration on the basis of pith dry matter among Metroxylon palms (Table 4.2). Metroxylon warburgii has a smaller trunk than sago palm, and the trunk of M. salomonense, M. vitiense, and M. amicarum is 
Table 4.1 Morphological characteristics of the genus Metroxylon

\begin{tabular}{|c|c|c|}
\hline Species & Distribution & Characteristics \\
\hline $\begin{array}{l}\text { M. sagu Rottb. } \\
\text { (Sago palm) }\end{array}$ & $\begin{array}{l}\text { Thailand, Malaysia, } \\
\text { Brunei, the } \\
\text { Philippines, } \\
\text { Indonesia, Papua } \\
\text { New Guinea, and the } \\
\text { Solomon Islands }\end{array}$ & $\begin{array}{l}\text { Clump forming. Spineless or spiny, with varying } \\
\text { spine length and density. Fruit is covered with } 18 \\
\text { rows of vertically arranged scales, } 5 \mathrm{~cm} \text { in diameter }\end{array}$ \\
\hline \multirow{2}{*}{$\begin{array}{l}\text { M. amicarum } \\
\text { (H. Wendl.) Becc. } \\
\text { (Caroline ivory } \\
\text { nut palm) }\end{array}$} & \multirow[t]{2}{*}{$\begin{array}{l}\text { Caroline Islands and } \\
\text { Micronesia }\end{array}$} & $\begin{array}{l}\text { Lateral inflorescence. First-order branches emerge at } \\
\text { leaf axils }\end{array}$ \\
\hline & & $\begin{array}{l}\text { Large globose fruit, } 26-29 \text { rows of scales, } 7-10.5 \mathrm{~cm} \\
\text { in diameter, slightly flat at top, no dent at base }\end{array}$ \\
\hline $\begin{array}{l}\text { M. vitiense } \\
\text { (H. Wendl.) } \\
\text { H. Wendl. ex } \\
\text { Benth. \& Hook. } \\
\text { f. (Fijian sago } \\
\text { palm) }\end{array}$ & Fiji Islands & $\begin{array}{l}\text { Second-order branches on inflorescence droop and } \\
\text { are very short }(18 \mathrm{~cm}) \text {. Spines on petiole and rachis } \\
\text { are black. Globose fruit, } 27-31 \text { rows of scales, } \\
\text { conical with round base and wide top, } 5.5-6.6 \mathrm{~cm} \text { in } \\
\text { length, } 4.5-7 \mathrm{~cm} \text { in diameter }\end{array}$ \\
\hline $\begin{array}{l}\text { M. salomonense } \\
\text { (Warb.) Becc. } \\
\text { (Solomons'sago } \\
\text { palm) }\end{array}$ & $\begin{array}{l}\text { The Solomon } \\
\text { Islands, Northeastern } \\
\text { part of New Guinea } \\
\text { Island, New Britain } \\
\text { Island, and Northern } \\
\text { islands in Vanuatu }\end{array}$ & $\begin{array}{l}\text { Third-order branches (rachillae) on inflorescence } \\
\text { droop and are very long }(20-26 \mathrm{~cm}) \text {, pubescence on } \\
\text { the adaxial side of all pedicel bracts. Spines on } \\
\text { petiole and rachis are soft. Inflorescence shows two } \\
\text { or three orders of branching. Rachillae arising as both } \\
\text { second-order branching on first-order branch of } \\
\text { inflorescence and third-order branching after } \\
\text { second-order branching. Globose fruit, } 27-28 \text { rows of } \\
\text { scales, } 7 \mathrm{~cm} \text { in diameter. Seed diameter: } 4 \mathrm{~cm} \text {; } \\
\text { pericarp thickness, } 5-6 \mathrm{~mm}\end{array}$ \\
\hline $\begin{array}{l}\text { M. warburgii } \\
\text { (Heim) Becc. } \\
\text { (Vanuatu sago } \\
\text { palm) }\end{array}$ & $\begin{array}{l}\text { Vanuatu, Fiji } \\
\text { (Rotuma Is.), Samoa }\end{array}$ & $\begin{array}{l}\text { All branches on inflorescence arising upright. No } \\
\text { pubescence on the adaxial side of all pedicel bracts. } \\
\text { Marked cuticle formation on the abaxial side of } \\
\text { leaflet. Pyriform fruit, } 24-28 \text { rows of scales, } 7-10 \mathrm{~cm} \\
\text { in length, } 4-9 \mathrm{~cm} \text { in diameter }\end{array}$ \\
\hline $\begin{array}{l}\text { M. paulcoxii } \\
\text { McClatchey (M. } \\
\text { upoluense Becc.) }\end{array}$ & Samoa & $\begin{array}{l}\text { Inflorescence shows two to three orders of branching, } \\
\text { rachillae arising nonuniformly (drooping or upright). } \\
\text { Second-order branches arising between the center } \\
\text { and tip of a first-order branch form rachillae, which } \\
\text { droop, and third-order branches arising between the } \\
\text { center and base of a second-order branch form } \\
\text { rachillae, which grow upright (two types of branching } \\
\text { pattern coexist at the central segment). Small fruit } \\
\text { narrowing toward base, length } 3.3 \mathrm{~cm} \text {, diameter } \\
2.5 \mathrm{~cm}, 24 \text { rows of scales }\end{array}$ \\
\hline
\end{tabular}

Sources: Rauwerdink (1986), McClatchey (1998), Ehara et al. (2003b), and Ehara 2015a (some information is from the latest survey by the author) 

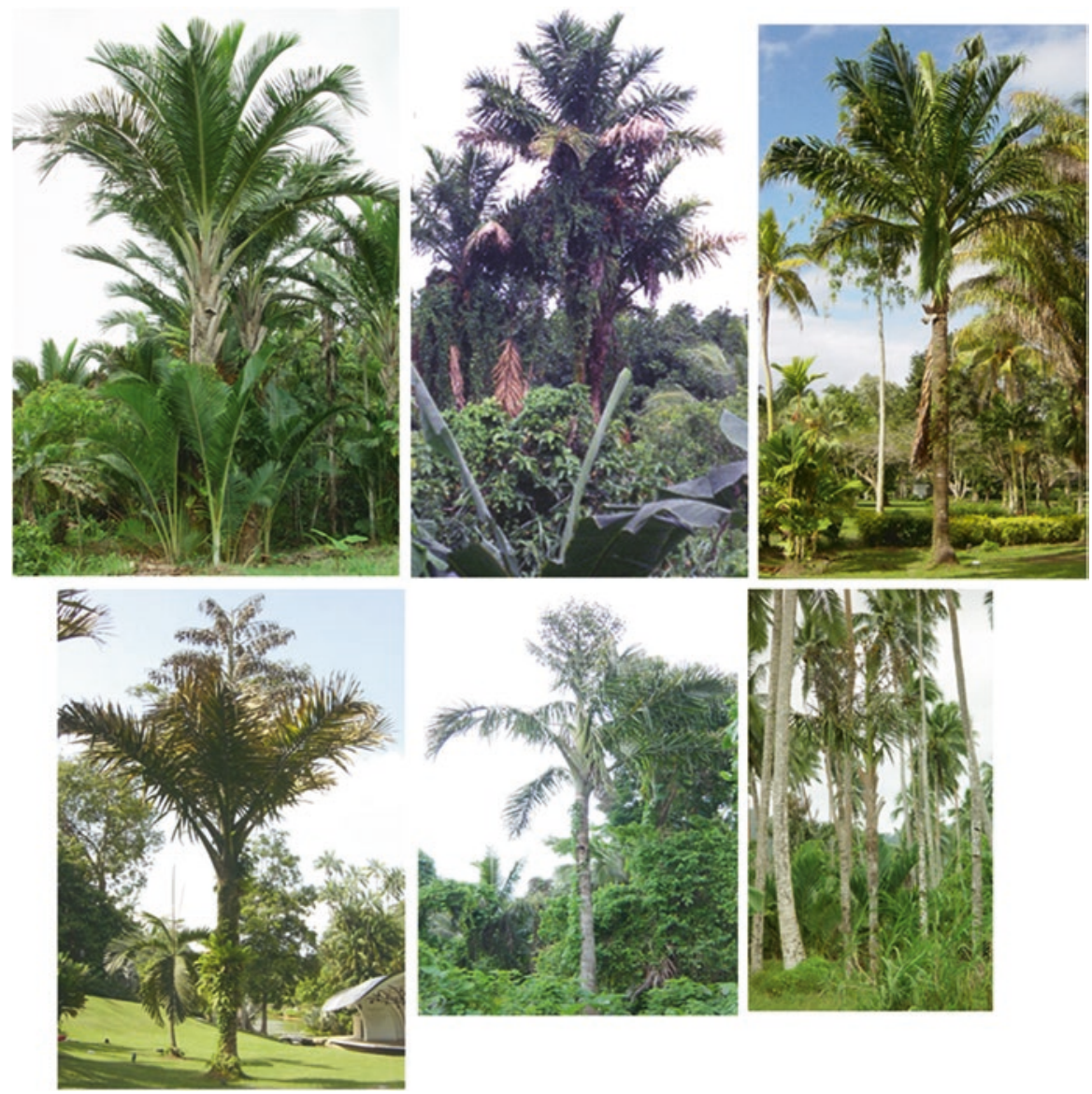

Fig. 4.1 Metroxylon palms (upper left, M. sagu; upper middle, M. amicarum; upper right, $M$. vitiense; lower left, M. salomonense; lower middle, M. warburgii; lower right, M. paulcoxii)

comparable to or longer than that of sago palm. However, M. salomonense, $M$. warburgii, $M$. vitiense, and $M$. amicarum are all low in their dry matter and starch contents of pith in comparison with sago palm. Therefore, the starch yield of $M$. salomonense and M. amicarum is low despite their larger trunk size. Coelococcus palms are mostly regarded as emergency crops as described above. They had been utilized when staple crops suffered environmental damage up to the 1950s or 1960s (Ehara et al. 2003b). Barton (2012) reported that the ethnographic record indicates that several groups of swidden farmers in Sarawak were still utilizing sago $(M$. $s a g u$ ) as their main crop, some used it on a regular basis, while others had shifted more fully toward rice, but were still dependent upon sago, and kept it nearby as insurance against a poor harvest or failure of the rice crop. It has been reported that salt was collected from the ashes of burned leaves in Vanuatu during the 1940s; similar examples were observed in PNG as well (Cabalion 1989). Currently, roof 
Table 4.2 Comparison of yield and yield components of the Metroxylon species

\begin{tabular}{l|l|l|l|l|l|l|l|l}
\hline $\begin{array}{l}\text { Species } \\
\text { (survey } \\
\text { location) }\end{array}$ & $\begin{array}{l}\text { Trunk } \\
\text { length } \\
(\mathrm{m})\end{array}$ & $\begin{array}{l}\text { Trunk } \\
\text { diameter } \\
(\mathrm{cm})\end{array}$ & $\begin{array}{l}\text { Pith } \\
\text { density } \\
\left(\mathrm{g} / \mathrm{m}^{3}\right)\end{array}$ & $\begin{array}{l}\text { Pith dry } \\
\text { matter } \\
\text { content } \\
(\%)\end{array}$ & $\begin{array}{l}\text { Pith dry } \\
\text { matter } \\
\text { weight } \\
(\mathrm{kg})\end{array}$ & $\begin{array}{l}\text { Pith } \\
\text { starch } \\
\text { content } \\
(\%)\end{array}$ & $\begin{array}{l}\text { Pith total } \\
\text { sugar } \\
\text { content } \\
(\%)\end{array}$ & $\begin{array}{l}\text { Starch } \\
\text { yield } \\
(\mathrm{kg} / \\
\mathrm{plant})\end{array}$ \\
\hline $\begin{array}{l}\text { M. sagu } \\
\text { (Indonesia) }\end{array}$ & 8.6 & 45.2 & 0.770 & 41.1 & 413.9 & 77.1 & $4.9^{\mathrm{a}}$ & 309.8 \\
\hline $\begin{array}{l}\text { M. } \\
\text { salomonense } \\
\text { (Vanuatu) }\end{array}$ & 8.5 & 58.0 & 0.850 & 18.5 & 326.0 & 48.9 & 15.3 & 159.4 \\
\hline $\begin{array}{l}\text { M. warburgii } \\
\text { (Vanuatu) }\end{array}$ & 5.5 & 35.0 & 0.902 & 35.7 & 156.5 & 34.8 & 13.5 & 48.6 \\
\hline $\begin{array}{l}\text { M. amicarum } \\
\text { (Micronesia) }\end{array}$ & 10.7 & 44.9 & 0.794 & 16.0 & 179.4 & 38.8 & 10.0 & 71.8 \\
\hline $\begin{array}{l}\text { M. vitiense } \\
\text { (Fiji) }\end{array}$ & 7.6 & 36.7 & 0.894 & 20.8 & 156.1 & 26.7 & 8.4 & 49.4 \\
\hline
\end{tabular}

Sources: Ehara et al. (2003c) and Ehara (2006b)

anly data of pith total sugar content was from PNG (mean value of two folk varieties used for food)

thatching is the most common use of Coelococcus palms, and the domestication of M. warburgii is currently under way in Vanuatu. In Samoa, M. warburgii can be recognized as a cultivated plant, and it is observed throughout Upolu Island.

\subsection{Origin and Distribution of Sago Palm and Related Species}

Sago palm is found in a zone $10^{\circ}$ north and south of the equator at the Malay Peninsula, from southern Thailand to western and eastern Malaysia, Brunei, Indonesia's Sumatra and surroundings, Java, Kalimantan, Sulawesi, the Maluku Islands, Papua and West Papua (formerly Irian Jaya), the central and southern Philippines, Papua New Guinea (PNG), and the Solomon Islands. This species has high environmental adaptability and can grow in lowland swamps, acidic soils, and brackish-water regions where other major crops cannot grow well. Sago palm grows wild near lakes and rivers and is found up to an elevation of about $700 \mathrm{~m}$ above sea level in North Sulawesi and about $1000 \mathrm{~m}$ in PNG. Wild stands of sago palms are found today primarily in swamps and peat moors which are unsuitable even for paddy rice. However, sago palm will show preferable production under upland condition with sufficient water where it in fact grows better than it does under flooded or submerged conditions. These days, sago palm stands are observed in places not suitable for agricultural development, which does not mean that lowland swamps are the most preferable habitat for sago palm (Ehara 2015b). 
Starch yield of sago palm varies greatly depending on both the habitat and the folk variety. Figure 4.2a shows the result of a random amplified polymorphic DNA (RAPD) analysis on a total of 38 population samples collected from 22 sites in the Malay Archipelago and 1 site in Papua New Guinea (PNG) (Ehara et al. 2003a). Among the 38 samples, 16 are spineless and 22 are spiny, including 14 gray or 2 with brown banding on the abaxial side of petiole/rachis, and 3 having reddish pith. The resultant UPGMA dendrogram divides the populations into two main groups. Group A includes subgroup A1 consisting of populations mainly distributed over the western part of the Malay Archipelago and subgroup A2 consisting of three populations from Southeast Sulawesi and two from Mindanao. Group B includes 12 populations collected in the eastern part of the Malay Archipelago: subgroup B1 consisting of 6 populations from Seram and subgroup B2 consisting of 2 from Seram and 4 from Ambon. From this analysis, a relationship between the genetic distance and geographical distribution of sago palms was found. A smaller genetic variation in the western part than in the eastern part of the Malay Archipelago was also found, which indicated that the more genetically varied populations are distributed in the eastern area. According to Vavilov's theory about centers of origin of cultivated plants, the origin of a plant taxon is the place where the highest diversity of that taxon is found. The origin of a plant species can be considered to be the place where the greatest number of varieties and other variants are found within the taxon. Based on the RAPD analysis, the greater genetic variation found in the eastern Malay Archipelago, including the Maluku Islands, supports the traditional hypothesis that the area from the Maluku Islands to New Guinea Island is the center of origin of the sago palm.

On the other hand, the genetic distance between the spineless and spiny populations is not necessarily farther than that between spineless populations or spiny populations in the dendrogram. This result indicated that the presence of spines on the petiole/rachis appears to be unrelated to genetic distance, which supports Rauwerdink's proposition (1986) to recognize the spineless sago palms and the spiny sago palms in the same taxon as $M$. sagu. Furthermore, no definite relationships were also found between the other morphological characteristics such as the banding pattern on petiole/rachis, the color of pith, and the genetic distances of populations. Kjær et al. (2004) have examined the relationships between various characteristics representing morphological features and genetic distances using amplified fragment length polymorphism (AFLP) analysis of sago palm populations growing in Papua New Guinea and reported that no correlations were found between different morphological characteristics and genetic distances. In communities that are highly dependent on sago palm, many folk varieties are recognized based on morphological traits. However, according to the past genetic diversity analyses conducted by Ehara et al. (2003a) and Kjær et al. (2004), the genetic diversity of the sago palm is not very high. Abbas et al. (2010) reported that a simple sequence repeat analysis of chloroplast DNA of plants collected from various locations in Papua Province of Indonesia has found that they are divided into three groups with about $77 \%$ belonging to one group. In any case, it is considered that there is no 


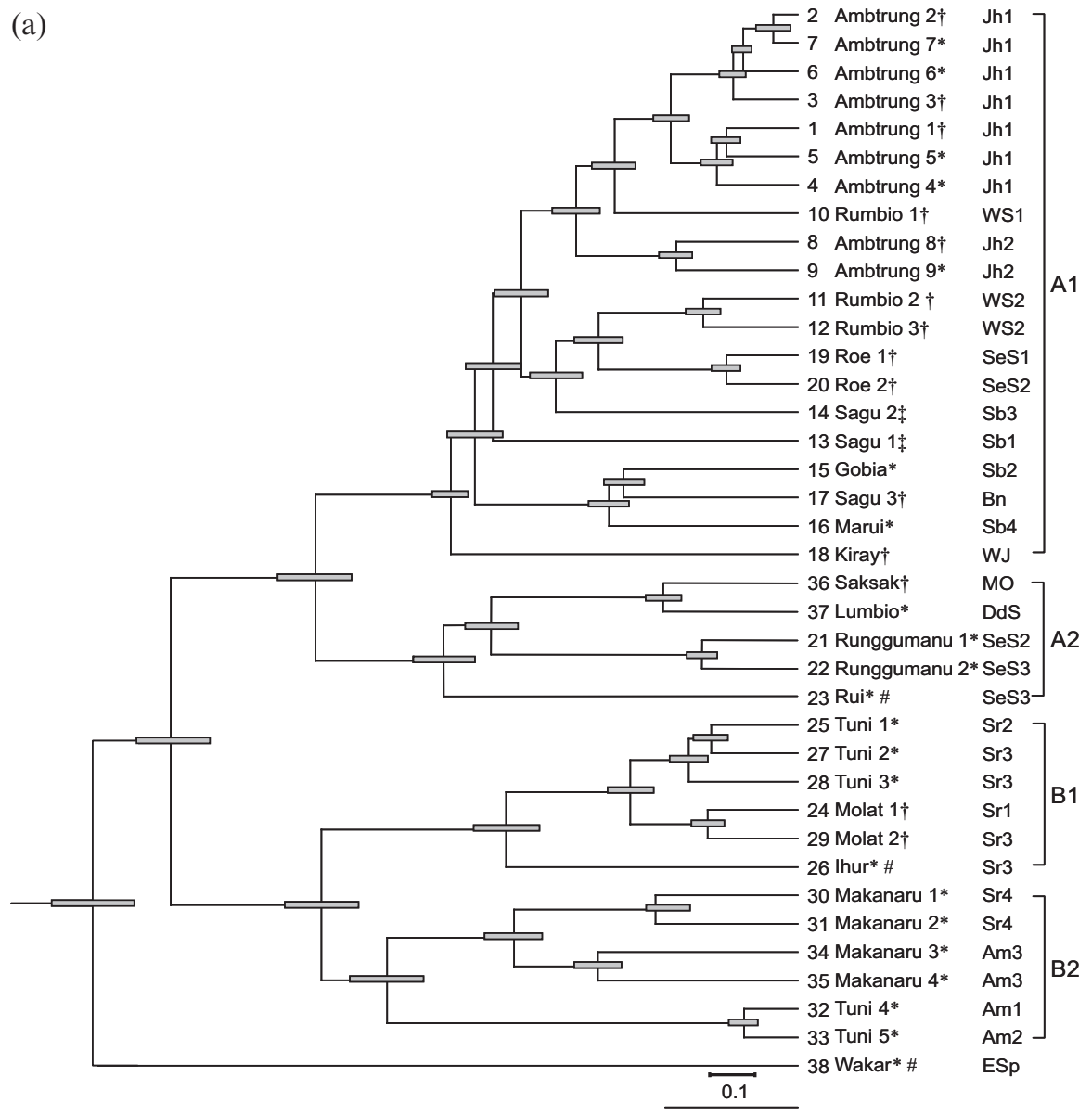

(b)

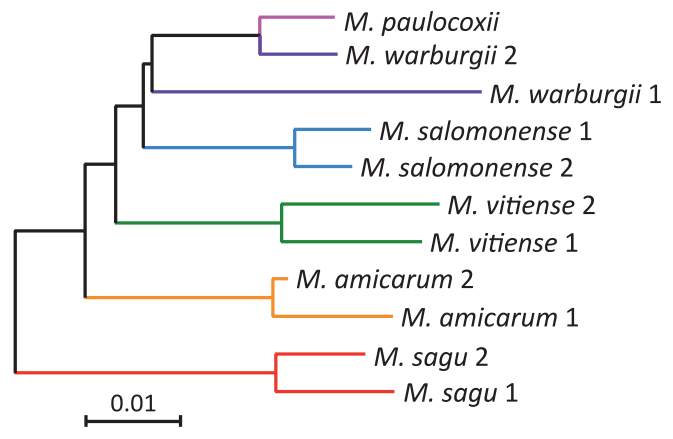

Fig. 4.2 UPGMA dendrogram of sago palm (M. sagu) based on RAPD data (a from Ehara et al. 2003a) and NJ dendrogram of genus Metroxylon based on sequence data of 5S nrDNA (b from Ehara et al. 2017) (* Spiny population, $\uparrow$ dark gray banding population, $\neq$ brown banding population, \# reddish pith population, $\square$ standard error) 
correspondence between morphological characteristics used for the folk classification in local communities and genetic distance.

Regarding the specifications of Metroxylon section Coelococcus, there are reports on the phylogenetics based on the morphological characters (McClatchey 1998, 1999). However, few studies of the molecular phylogenetics on the section Coelococcus exist. Baker et al. (2000) reported molecular phylogenetics of Calamus and related rattan genera based on $5 \mathrm{~S}$ nrDNA spacer sequence data. The phylogenetic analysis based on 5S nrDNA spacer sequence is considered to be available for the genus Metroxylon that belongs to the same tribe (Calameae) with the genus Calamus. Figure $4.2 \mathrm{~b}$ shows the results of the phylogenetic analysis using DNA sequence data from the nontranscribed spacer of 5S nrDNA to investigate phylogenetic relationships among the species of section Coelococcus. Two populations each of M. salomonense, $M$. warburgii, $M$. amicarum, $M$. vitiense, and sago palm (M. sagu grown in Southeast Sulawesi) as the out-group were used in this analysis. In only $M$. paulcoxii, one palm was used because only one individual was found on Upolu in Samoa in 2004. According to the NJ dendrogram from the cladistic analysis, the section Coelococcus was divided into four clades. Metroxylon amicarum grown in Micronesia was genetically distant from the other species in the section Coelococcus. Metroxylon amicarum grown in Micronesia is markedly different from the other species in inflorescence development as described above. Metroxylon salomonense and $M$. vitiense clearly are at or near the purely hapaxanthic definition, and $M$. amicarum is not as clearly near the pleonanthic definition but is close enough to be categorized as pleonanthic, whereas populations of $M$. warburgii and $M$. paulcoxii are intermediate, tending to be closer a hapaxanthic than to a pleonanthic condition (McClatchey 1999).

Metroxylon warburgii formed a clade together with $M$. paulcoxii in this analysis. The other species of the section Coelococcus formed their own clade. M. paulcoxii was reported by McClatchey (1998) as a new species. This species has a reduced floral branching system, which is completely different from the other Metroxylon species including the section Metroxylon (sago palm). Genetic relationship between M. paulcoxii and $M$. warburgii should be studied in detail employing further analysis from the molecular phylogenetic point of view. Besides, the distribution area of $M$. warburgii is very wide from Vanuatu to Vanua Levu Island and Rotuma Island of Fiji and Samoa that is geographically distant from that of sago palm. The clade of $M$. warburgii and $M$. paulcoxii was located at the most distant position from sago palm in this dendrogram. From this analysis, it can be considered that the species in the section Coelococcus were dispersed by two routes: one was to the north for Micronesia, and the other route was to the east for Polynesia through Melanesia. This is in agreement with McClatchey's study (1999) based on phylogenetic analysis using morphological characters. 


\subsection{Resistance Against Abiotic Stresses}

\subsubsection{Salt Stress}

As mentioned above, Metroxylon palms can grow in problem soils. Here, the salt resistance of sago palm and related species is introduced. Figure 4.3a shows the $\mathrm{Na}^{+}$ concentration in different plant parts of sago palm seedlings grown in a hydroponic system after $342 \mathrm{mM} \mathrm{NaCl}$ treatment (corresponding to $2 \% \mathrm{NaCl}$ ) for 1 month (Ehara et al. 2008b). In the leaflets and petioles of the treated plants, the $\mathrm{Na}^{+}$ concentrations were higher at lower leaf positions than at higher leaf positions. The difference in the $\mathrm{Na}^{+}$concentrations in both the leaflets and petiole between the control and treated plants was remarkable at lower leaf positions. The $\mathrm{Na}^{+}$ concentration in the leaflets was less than one-half of that in the petiole. On the other hand, the $\mathrm{Cl}^{-}$concentration increased with the $\mathrm{NaCl}$ treatment in all the parts including the leaflets at nearly all the leaf positions (Ehara et al. 2008b). The pattern of the difference in the $\mathrm{Cl}^{-}$concentration was different from that in the $\mathrm{Na}^{+}$ concentration, especially in the petiole.

Although the $\mathrm{K}^{+}$concentration decreased in the roots during the $\mathrm{NaCl}$ treatment, it did not decrease in the leaflets and petiole. These tendencies were found in the seedlings at more advanced leaf ages as well and under a wide range of $\mathrm{NaCl}$ concentrations in culture solution (Ehara et al. 2006). At some leaf positions, the $\mathrm{K}^{+}$ concentrations were higher in the treated plants than in the control plants (Ehara et al. 2008a, b). The $\mathrm{K}^{+}$concentration in the petiole tended to be higher at higher leaf positions than at lower leaf positions, especially in the treated plants. In some species, plant growth is not affected when the $\mathrm{K}^{+}$concentration is maintained under $\mathrm{NaCl}$ treatment (Yeo and Flowers 1983; Jeschke et al. 1985). The $\mathrm{K}^{+}$concentrations in the top part did not decrease, regardless of the leaf position in the case of sago palm. It appears that $\mathrm{Na}^{+}$absorption clearly did not depress $\mathrm{K}^{+}$absorption and translocation to the leaves in sago palm, and the $\mathrm{K}^{+}$distribution in the top part tended to increase rather than have no effect. Yoneta et al. (2006) also reported that sago palm was able to uptake $\mathrm{K}^{+}$from soil, and $\mathrm{K}^{+}$was accumulated in leaflets through the root systems in response to $\mathrm{NaCl}$ stress. They reported also that proline was under the detection limit in leaflets and roots, and a small amount of glycinebetaine was found in leaflets.

According to Ehara et al. (2008a, b), new leaf emergence was delayed slightly with the $\mathrm{NaCl}$ treatment, although senescence of the lower leaf did not accelerate. In $M$. warburgii and $M$. vitiense also, the $\mathrm{K}^{+}$concentration in the leaflets did not decrease under salt stress conditions (Ehara et al. 2007, 2008a). These results in sago palm and related species strongly support the assumption that salt tolerance is related to the exclusion of $\mathrm{K}^{+}$by $\mathrm{Na}^{+}$absorption in the leaf blade (Yeo and Flowers 1983; Jeschke et al. 1985). Considering these results, $\mathrm{K}^{+}$assumes the role of osmotic adjustment, especially at higher leaf positions in most active leaves. 
a

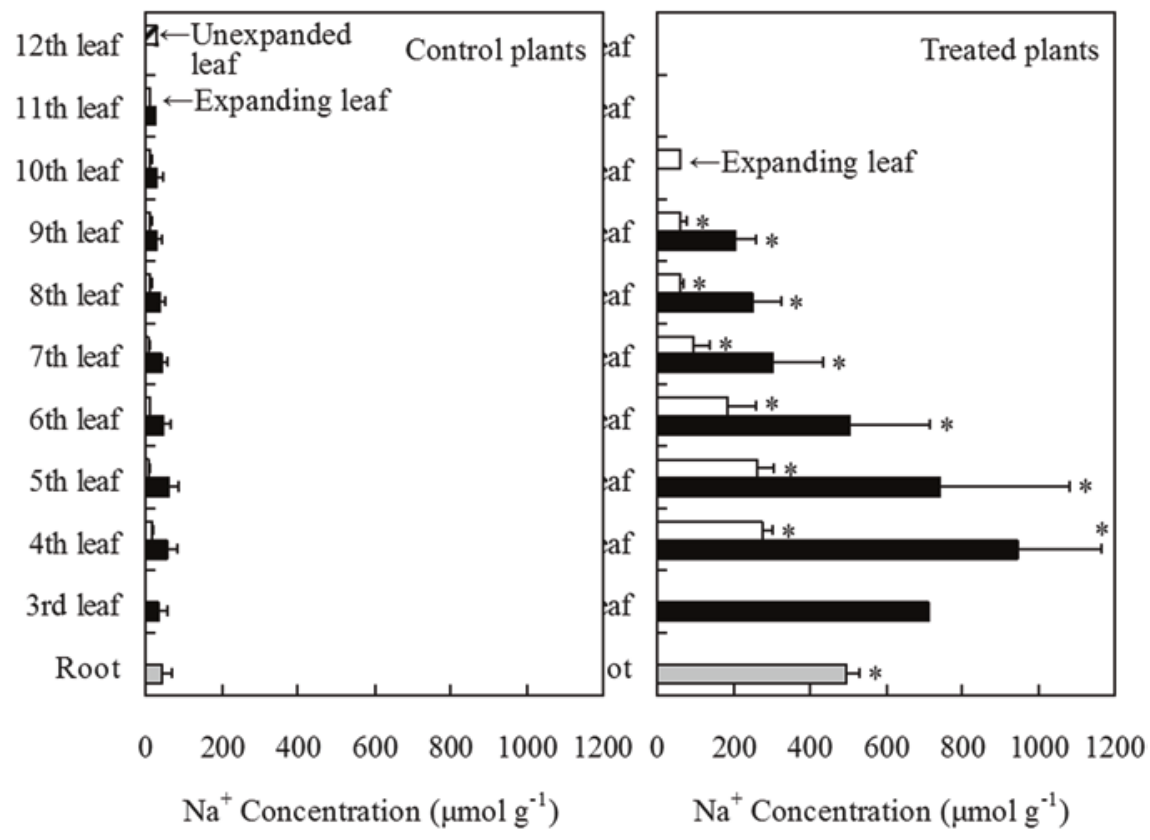

b
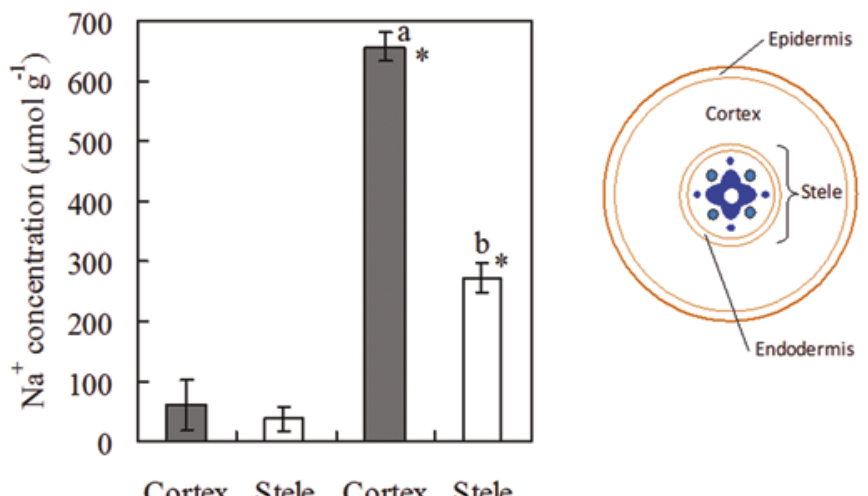

Cortex Stele Cortex Stele

Control Treatment

Fig. 4.3 $\mathrm{Na}^{+}$concentration in roots and leaflets and petiole at different leaf positions (a) and in the cortex and stele of adventitious roots under $\mathrm{NaCl}$ treatment (b) (Source: Ehara et al. 2008a) with schematic of transvers section of root (c). Horizontal and vertical lines indicate the standard deviation $(n=3)$. Asterisks indicate a significant difference in each part between the control and treated plants at a 0.05 probability level, according to the t-test. Different letters indicate significant differences in different parts within the treated plants at a 0.05 probability level, according to the Tukey-Kramer test 
Figure $4.3 \mathrm{~b}$ shows the $\mathrm{Na}^{+}$concentration in different parts in the adventitious roots (Ehara et al. 2008b), and Fig. 4.3c shows a schematic of transverse section of root. The $\mathrm{Na}^{+}$concentration was lower in the stele (central cylinder) than in the cortex. According to the study on Na distribution revealed by X-ray microanalysis from the cortex to the stele in the adventitious roots of the treated plants, much more $\mathrm{Na}$ was detected in the cortex than in the stele (Ehara et al. 2008b). The highest distribution of $\mathrm{Na}$ was found at the inner region of the cortex near the stele. In this region, the endodermis where suberin or lignin (Casparian strip) develops also was observed in sago palm (Prathumyot and Ehara 2010). From only this finding, it is difficult to discuss the information in detail, although it is clear that the region including the endodermis has a mechanism to trap some of the over-influx of $\mathrm{Na}$ into the root. This mechanism will be very important in restricting translocation of $\mathrm{Na}^{+}$from the root to the top parts under salt stress. Sago palm exhibits the mechanism to maintain low $\mathrm{Na}^{+}$concentration in the leaflets by storing $\mathrm{Na}^{+}$in the roots and petioles, especially at lower leaf positions, the mechanism of which can be understood as salt avoidance. However, the photosynthetic rate and transpiration rate decreased by $40 \%$ with $\mathrm{NaCl}$ stress in sago palm seedlings (final 18th leaf age) grown for 4 months in a hydroponic system including $224 \mathrm{mM} \mathrm{NaCl}$ (corresponding to $1.3 \%$ ) (Prathumyot et al. 2011).

\subsubsection{Acid Stress}

Nowadays sago palm populations are often found in swamps and peat soil where soil $\mathrm{pH}$ is low, such as in the Malay Archipelago. Sago palm has been considered to be tolerant of acid soil. From the results of growth analysis of sago palm seedlings

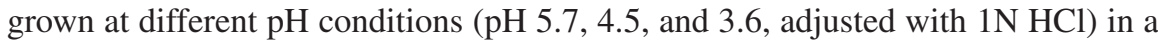
pot filled with vermiculite and culture solution for 4.5 months, it was clear that there were no significant differences in any growth parameters among the three treatments (Anugoolprasert et al. 2012). When sago palm seedlings were planted in a pot filled with vermiculite and culture solution at $\mathrm{pH} 3.6$ (adjusted with $1 \mathrm{~N} \mathrm{H}_{2} \mathrm{SO}_{4}$ ) that included different levels of $\mathrm{AlCl}_{3} \cdot 6 \mathrm{H}_{2} \mathrm{O}$ corresponding to $0,10,20,100$, and $200 \mathrm{ppm} \mathrm{Al}$ (as initial Al concentration before applying to the pots), the weekly increments of plant length, total leaf area, and dry matter weight for 4.5 months were largest in 10 ppm, followed by 0, 20, 100, and 200 ppm Al (Anugoolprasert et al. 2014). The root system under $200 \mathrm{ppm}$ Al was apparently different from that under 0-100 ppm Al, and the branched roots were stunted, brownish, and thick. The root dry weight was also less than the other plots. The change in $\mathrm{P}, \mathrm{N}, \mathrm{K}^{+}, \mathrm{Ca}^{2+}$, and $\mathrm{Mg}^{2+}$ concentrations with the $\mathrm{Al}$ treatments was moderate. The $\mathrm{Al}^{3+}$ concentration tended to be lower in the leaflets at higher leaf position and the stele of the adventitious roots, while it tended to be higher in the cortex of adventitious roots (values ranged from 190 to $950 \mathrm{mg} \mathrm{kg}^{-1} \mathrm{DM}$ in all the plant parts, even at $200 \mathrm{ppm}$ Al). According to Chenery (1948), thousands of plant species are classified as Al 
accumulators ( $\left.\geq 1000 \mathrm{mg} \mathrm{kg}^{-1} \mathrm{DM}\right)$ or Al excluders ( $\left.<1000 \mathrm{mg} \mathrm{kg}^{-1} \mathrm{DM}\right)$. Based on the $\mathrm{Al}$ concentrations in the plant tissues, sago palm is considered to have Al-exclusion ability under acidic conditions. However, the diameter at breast height (DBH) that was one of the most important parameters limiting the pith dry matter yield correlated with soil $\mathrm{pH}$ in the Malay Archipelago (Ehara et al. 2000). Even if sago palm exhibits the mechanism to exclude excess $\mathrm{Al}$ under low $\mathrm{pH}$ condition, the growth and yield will be affected by soil acidity.

Although sago palm can adapt to comparatively severe environments such as saline or acid soils, the growth rate and productivity will be decelerated under salt stress or in acid soil. We should investigate how much sago starch we can expect to produce under saline or acid condition to utilize areas of poor productivity or barren lands with sterile soil. The physiological information described above on the growth of sago palm and its response to abiotic stresses will be valuable for investigating concrete tactics and/or strategies to introduce new plant resources to barren lands with sterile soil and improve the economic activities depending on regional resources in places with low productivity.

\section{References}

Abbas B, Renwarin Y, Bintoro MH et al (2010) Genetic diversity of sago palm in Indonesia based on chloroplast DNA (cpDNA) markers. J Biol Div 11:112-117

Anugoolprasert O, Kinoshita S, Naito H et al (2012) Effect of low pH on the growth, physiological characteristics and nutrient absorption of sago palm in a hydroponic system. Plant Prod Sci $15: 125-131$

Anugoolprasert O, Ehara H, Naito H (2014) Growth response and nutrient concentrations of sago palm under aluminum stress. TIJSAT 19:37-52

Baker JB, Henderson TA, Dransfield J (2000) Molecular phylogenetics of Calamus (Palmae) and related rattan genera based on 5S nrDNA spacer sequence data. Mol Phylogenet Evol 14:218-231

Barrau J (1959) The sago palm and other food plants of marsh dwellers in the South Pacific Islands. Econ Bot 13:151-159

Barton H (2012) The reversed fortunes of sago and rice, Oryza sativa, in the rainforests of Sarawak, Borneo. Quat Int 249:96-104

Beccari O (1918) Asiatic palms-Lepidocaryae. Ann R Bot Gard Calcutta 12:156-195

Cabalion P (1989) Metroxylon, Vanuatu palm. In: Dowe JL (ed) Palms of the south-West Pacific. Palm and Cycad Societies of Australia, Milton, pp 178-180

Chenery EM (1948) Aluminium in the plant world. I. General survey in dicoyledons. Kew Bull 2:173-183

Dowe JL (1989) Palms of the south-West Pacific: their origin, distribution and description. In: Dowe JL (ed) Palms of the South-West Pacific. Palm and Cycad Societies of Australia, Milton

Ehara H (2006a) Diversity of economic plants. In: Morita S, Daimon H, Abe J (eds) Sustainable crop production. Asakura Shoten, Tokyo, pp 25-28

Ehara H (2006b) Geographical distribution and specification of Metroxylon palms. Jpn J Trop Agric 50:229-233

Ehara H (2015a) Taxonomy. In: The sago palm: the food and environmental challenges of the 21st Century. Kyoto University Press, Kyoto and Trans Pacific Press, Melbourne, pp 1-16 
Ehara H (2015b) Geographical origin, dispersal and distribution of true sago palm. In: The sago palm: the food and environmental challenges of the 21st Century. Kyoto University Press, Kyoto and Trans Pacific Press, Melbourne, pp 17-22

Ehara H (2015c) Use of trunk apex. In: The sago palm: the food and environmental challenges of the 21st Century. Kyoto University Press, Kyoto and Trans Pacific Press, Melbourne, pp 302-304

Ehara H (2015d) Use of fruit. In: The sago palm: the food and environmental challenges of the 21st Century. Kyoto University Press, Kyoto and Trans Pacific Press, Melbourne, pp 304-307

Ehara H, Susanto S, Mizota C et al (2000) Sago palm (Metroxylon sagu, Arecaceae) production in the eastern Archipelago of Indonesia: variation in morphological characteristics and pith-dry matter yield. Econ Bot 54:197-206

Ehara H, Kosaka S, Shimura N et al (2003a) Relationship between geographical distribution and genetic distance of sago palms in the Malay Archipelago. Sago Palm 11:8-13

Ehara H, Naito H, Mizota C, Ala P (2003b) Distribution, growth environment and utilization of Metroxylon palms in Vanuatu. Sago Palm 10:64-72

Ehara H, Naito H, Mizota C, Ala P (2003c) Agronomic features of Metroxylon palms growing on Gaua in the Banks Islands, Vanuatu. Sago Palm 11:14-17

Ehara H, Matsui M, Naito N (2006) Avoidance mechanism of salt stress in sago palm (Metroxylon sagu Rottb.) Jpn J Trop Agric 50:36-41

Ehara H, Shibata H, Naito $\mathrm{H}$ et al (2007) $\mathrm{Na}^{+}$and $\mathrm{K}^{+}$concentrations in different plant parts and physiological features of Metroxylon warburgii Becc. Under salt stress. Jpn J Trop Agric 51:160-168

Ehara H, Shibata H, Prathumyoto W et al (2008a) Absorption and distribution of $\mathrm{Na}^{+}, \mathrm{Cl}^{-}$and some other ions and physiological features of sago palm under salt stress. Trop Agric Dev 52:7-16

Ehara H, Shibata H, Prathumyot W et al (2008b) Absorption and distribution of $\mathrm{Na}^{+}$and some ions in seedlings of Metroxylon vitiense H. Wendl. ex Benth. \& Hook. f. Under salt stress. Trop Agric Dev 52:17-26

Ehara H, Yamamoto T, Naito H et al (2017) Phylogenetic study of Metroxylon palms in Southeast Asia and Oceania based on 5S nrDNA spacer sequence data. SAGO PALM (in press)

Jeschke WD, Atkins CA, Pate JS (1985) Ion circulation via phloem and xylem between root and shoot of nodulated white lupin. J. Plant Physiol 117:319-330

Jong FS (1995) Research for the development of sago palm (Metroxylon sagu Rottb.) cultivation in Sarawak, Malaysia. Ph. D. thesis of Agricultural University, Wageningen, The Netherlands

Kjær AS, Barfod AS, Asumussen CB et al (2004) Investigation of genetic and morphological variation in the sago palm (Metroxylon sagu; Arecaceae) in Papua New Guinea. Ann Bot 94:109-117

McClatchey WC (1998) A new species of Metroxylon (Arecaceae) from Western Samoa. Novon 8:252-258

McClatchey WC (1999) Phylogenetic analysis of morphological characteristics of Metroxylon section Coelococcus (Palmae) and resulting implications for studies of other Calamoideae genera. Mem N Y Bot Gard 83:285-306

Prathumyot W, Ehara H (2010) Identification of Casparian strip in roots of Metroxylon sagu, a salt-resistant palm. Trop Agric Dev 54:91-97

Prathumyot W, Okada M, Naito H et al (2011) Physiological response and mineral concentration of sago palm under diurnal changes of $\mathrm{NaCl}$ concentration in culture solution. Trop Agric Dev $55: 11-20$

Rauwerdink JB (1986) An essay on Metroxylon, the sago palm. Principes 30:165-180

Sato T, Yamaguchi T, Takamura T (1979) Cultivation, harvesting and processing of sago palm. Jpn J Trop Agric 23:130-136

Takamura T (1990) Recent research activities and the problems on sago palm. Jpn J Trop Agric 34:51-58. (in Japanese) 
Yang X, Barton HJ, Wan Z et al (2013) Sago-type palms were an important plant food prior to rice in southern subtropical china. PLoS One 8(5):e63148. doi:10.1371/journal.pone.0063148

Yeo AR, Flowers TJ (1983) Varietal differences in the toxicity of sodium ions in rice leaves. Physiol Plant 59:189-195

Yoneta R, Okazaki M, Yano Y (2006) Response of sago palm (Metroxylon sagu Rottb.) to $\mathrm{NaCl}$ stress. Sago Palm 14:10-19

Open Access This chapter is licensed under the terms of the Creative Commons Attribution 4.0 International License (http://creativecommons.org/licenses/by/4.0/), which permits use, sharing, adaptation, distribution and reproduction in any medium or format, as long as you give appropriate credit to the original author(s) and the source, provide a link to the Creative Commons license and indicate if changes were made.

The images or other third party material in this chapter are included in the chapter's Creative Commons license, unless indicated otherwise in a credit line to the material. If material is not included in the chapter's Creative Commons license and your intended use is not permitted by statutory regulation or exceeds the permitted use, you will need to obtain permission directly from the copyright holder. 